\title{
Super sizing the giants: first cartilage preservation at a sauropod dinosaur limb joint
}

\author{
DANIELA SCHWARZ ${ }^{1}$, OLIVER WINGS ${ }^{2} \&$ CHRISTIAN A. MEYER ${ }^{1}$ \\ ${ }^{1}$ Naturhistorisches Museum Basel, Augustinergasse 2,CH-4001 Basel, Switzerland (e-mail: Daniela.Schwarz@bs.ch) \\ ${ }^{2}$ Institut für Geowissenschaften, Universität Tübingen, Sigwartstrasse 10, D-72076 Tübingen, Germany
}

\begin{abstract}
Re-examination of the sauropod dinosaur Cetiosauriscus greppini von Huene 1922 (Reuchenette Formation; Kimmeridgian, Late Jurassic) from northwestern Switzerland has revealed a well-preserved cartilage capsule at the distal extremity of the right humerus. The capsule represents hyaline cartilage together with fibrocartilage and can be distinguished by colour, surface structure and histology from the periosteum of the bone. This is the first fossil evidence for articular cartilage in a sauropodomorph dinosaur. It indicates the presence of a large articular capsule on sauropod forelimbs, which was only hypothesized until now, and shows that the forelimb length of sauropods was larger than previously assumed.
\end{abstract}

The remains of the sauropod dinosaur Cetiosauriscus greppini von Huene 1922 were found in the 1860 s at the 'Basse Montagne' quarry near Moutier, Switzerland (Fig. 1; Greppin 1870; von Huene 1922, 1927). The bones, found within a greenish lens of marls and limestone (von Huene 1922; Jank et al. 2006), belong to the lower part of the Reuchenette Formation, of Early Kimmeridgian (sensu gallico) age (Meyer \& Thüring 2003). Removed matrix contained charcoal remains as well as fist-sized rhizolith concretions embedded in a clay matrix, indicating deposition in an ephemeral lake without transport by currents.

The skeletal remains were originally described as Ornithopsis greppini by von Huene (1922), but later, in combination with the skeleton BMNH (Natural History Museum London) R3078 (= Cetiosaurus leedsi, Woodward 1905) from England, included in the new genus Cetiosauriscus von Huene 1927. BMNH R3078 was renamed as Cetiosauriscus stewarti Charig 1980 and established as the type specimen of Cetiosauriscus (Charig 1993), whereas C. greppini is considered a nomen dubium (Glut 1994). The skeletal remains of C. greppini can be assigned to three individuals of different sizes. The studied right humerus NMB (Naturhistorisches Museum Basel) MH 260 belongs to the holotype (von Huene 1922), an adult individual c. $10 \mathrm{~m}$ long. The left humerus (NMB MH 341) of this holotype lacks its proximal third and has a badly damaged distal articular surface.

\section{Methods}

For the histological study, a core of cartilage and bone material was extracted from the cranial face of the distal extremity of the humerus, located in the centre of its medial third. Drilling was performed using a diamond-sintered hollow-drill with a wall-diameter of $0.3 \mathrm{~mm}$, producing a core with a diameter and a depth of $6 \mathrm{~mm}$. During extraction, the core broke into several pieces and was subsequently glued. The core was cut lengthwise and processed into a standard petrographic thin section.

The thin section was first examined with a light microscope, and was then carbon-coated for study with a LEO VP 1450 SEM. The elemental composition of sample points was measured using an energy-dispersive X-ray analyser (EDX) with a LINK Pentafet Si (Li)-drifted detector crystal (Oxford Instruments INCA EDS 200 microanalysis system). Operating parameters were $15 \mathrm{kV}$ at $2.575 \mathrm{~A}$ with a working distance of $15 \mathrm{~mm}$ and a measuring time of $60 \mathrm{~s}$.

\section{Description}

The humerus MH 260 is strongly proximodistally compressed (Fig. 2a and b). The distal articular surface has been partially abraded post mortem at its cranial face, exposing the internal spongiosa (Fig. 2b). Cracks and fractures of the bone are filled by sediment. The cartilage can clearly be distinguished from the brown bone surface by its light grey colour, and extends over much of the distal humeral extremity (Fig. 2a and b). The greatest thickness of cartilage is preserved in morphological depressions of the bone surface. In areas where the cartilage and cortical bone are completely broken off, the underlying bone surface is exposed. The contact between bone and overlying cartilage is sharp and the cartilage is poorly bound to the bone. At the drill-hole (Fig. 2c), the cartilage is about $3 \mathrm{~mm}$ thick.

Cartilage covers the caudal face of the distal humeral extremity except at its lateral third. In the olecranon fossa (Fig. 2a), the preserved cartilage layer is approximately three times as thick as on the rest of the surface. It extends at the medial end of the olecranon fossa with a tongue-shaped projection for $18.9 \mathrm{~cm}$ proximally, approximately one-third of the $52.3 \mathrm{~cm}$ total length of the humerus (Fig. 2a). At the broadened medial margin of the humerus, the cartilage is preserved as a thin layer on the most distal $9.5 \mathrm{~cm}$.

The cranial face of the distal humeral extremity is completely covered by cartilage, which has its greatest thickness in the depressions laterally and medially to the lateral ridge (Fig. 2b). The cartilage extends for $11.5 \mathrm{~cm}$ proximally at the lateral ridge and the lateral margin, and for $8.5 \mathrm{~cm}$ proximally in the depressions laterally and medially to the lateral ridge. On contact with the humeral shaft, the cartilage spreads out into lobe-like extensions.

The surface of the cartilaginous structure is crossed by proximodistally directed furrows and ridges of $1-2 \mathrm{~mm}$ width and $2-5 \mathrm{~mm}$ apart (Fig. 2c), best developed in the olecranon depression, the depressions on the cranial face of the humerus, and on the lateral humeral margin. Some furrows extend up to $5 \mathrm{~mm}$ into the cartilage and reach the underlying bone surface. The cartilage bears circular perforating pores with diameters of $0.5-1.5 \mathrm{~mm}$ (Fig. 2c). In the depression between medial and lateral ridge on the cranial humeral face, the cartilage is irregularly convex and bears more densely packed pores. The underlying bone surface is smooth with a few fine longitudinal striae. At the lateral third of the caudal articular surface, and 


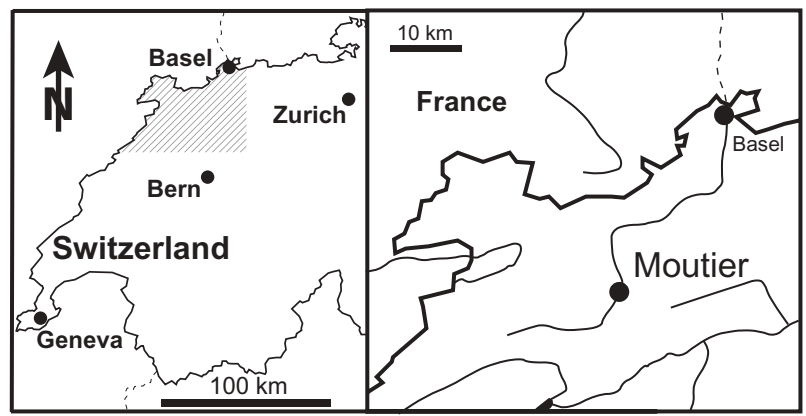

Fig. 1. Field locality of Cetiosauriscus greppini at the 'Basse Montagne' quarry near Moutier, Switzerland. Swiss coordinates: 123.753/259.535; UTM: $7^{\circ} 22^{\prime} 37.66^{\prime \prime}, 47^{\circ} 17^{\prime} 19.04^{\prime \prime}$.

distally at the cranial articular surface, the bone exposes longitudinal furrows of c. $0.5 \mathrm{~mm}$ width.

Under the microscope, the cartilage is interspersed by tiny, densely spaced foramina with $0.1-0.3 \mathrm{~mm}$ diameter and an irregular outline. The surface around the foramina appears dense and amorphous. The exposed spongiosa of the underlying bone is composed of a meshwork of thick trabeculae forming larger cavities with $c .1 \mathrm{~mm}$ diameter.
The thin section reveals two clearly distinctive tissues: (1) the external surface of the bone is covered by a mineralized tissue with closely spaced circular pores, identified as mineralized cartilage (e.g. Horner et al. 2000); (2) the bone itself is composed of fibro-lamellar tissue, with primary osteons and large vascular canals preserved (Figs 3 and 4). SEM-EDX examination revealed that both tissues are composed of apatite with a similar distribution of the elements $\mathrm{Ca}, \mathrm{O}$ and $\mathrm{P}$ at all sampled locations (Fig. 3). The bone cavities as well as the cartilage cavities are filled with sparry calcite, which is the most common cavity-filling mineral in fossil bone (Wings 2004).

The homogeneous matrix of the tissue is typical of hyaline cartilage (Francillon-Vieillot et al. 1990). The matrix contains abundant dark brown chondrocytes (Fig. 4), distributed irregularly and densely within the matrix. Interwoven fibrous metaplastic tissue exists in places (Fig. 4b). The calcified cartilage shows rather irregular vascular spaces with a spongy appearance. The macroscopic foramina with a diameter between 0.1 and $0.3 \mathrm{~mm}$ appear in the thin section as perforated marrow spaces (Fig. 4b). Long columns of chondrocytes, as in longitudinal sections of bones of Maiasaura (Horner et al. 2000), are not visible, presumably because of the transverse plane of section. There is no defined absorption zone, in which calcified cartilage was resorbed and replaced by endochondral bone.
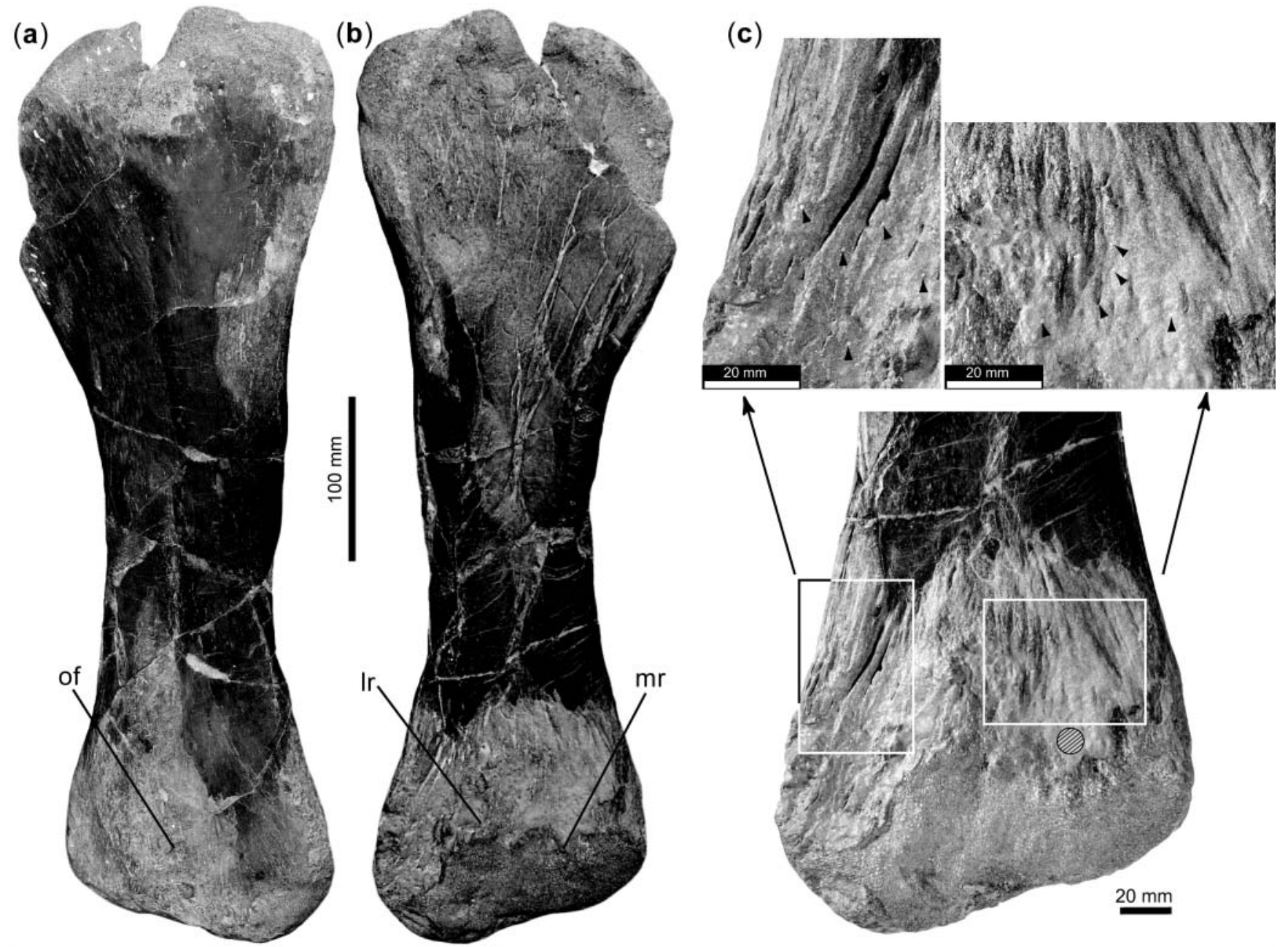

Fig. 2. Photographs of right humerus MH 260 of Cetiosauriscus greppini, in (a) caudal aspect and (b) cranial aspect. (c) Close-up of distal articular surface with cartilage in cranial aspect; the hatched circle is marking position of the drill-hole; black arrows show some of the circular pores at the cartilage. lr, lateral ridge; mr, medial ridge; of, olecranon fossa. 

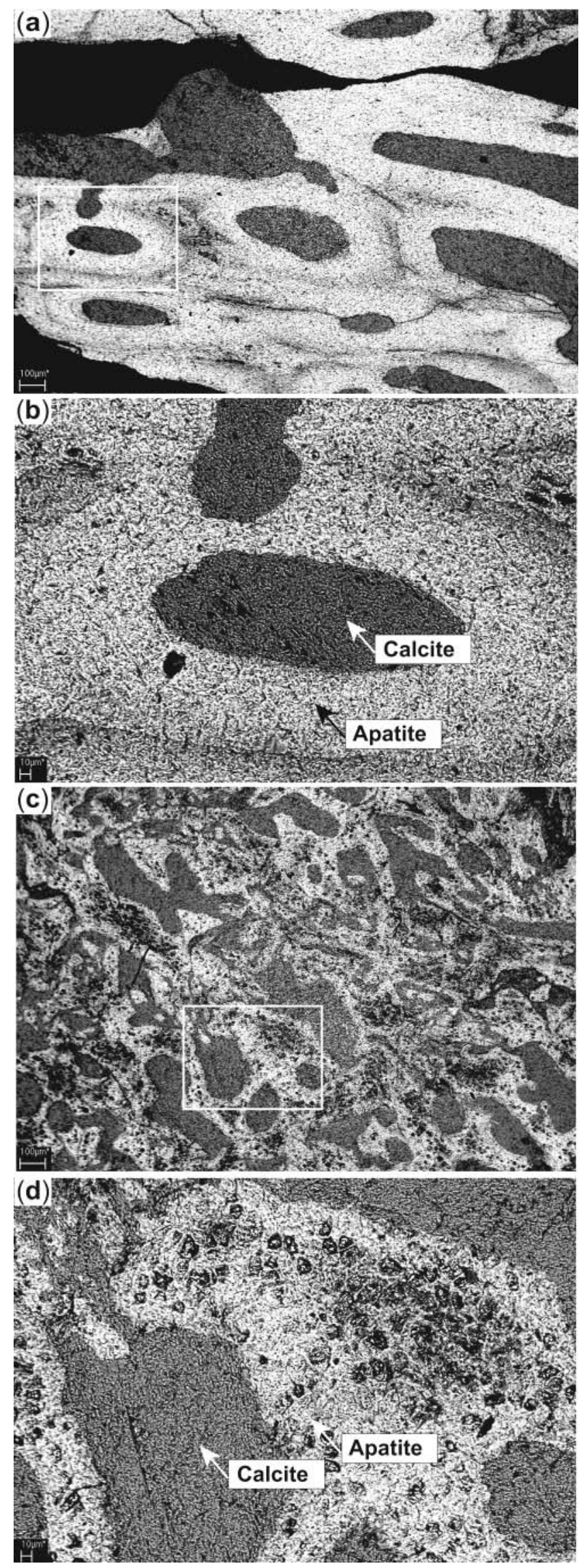
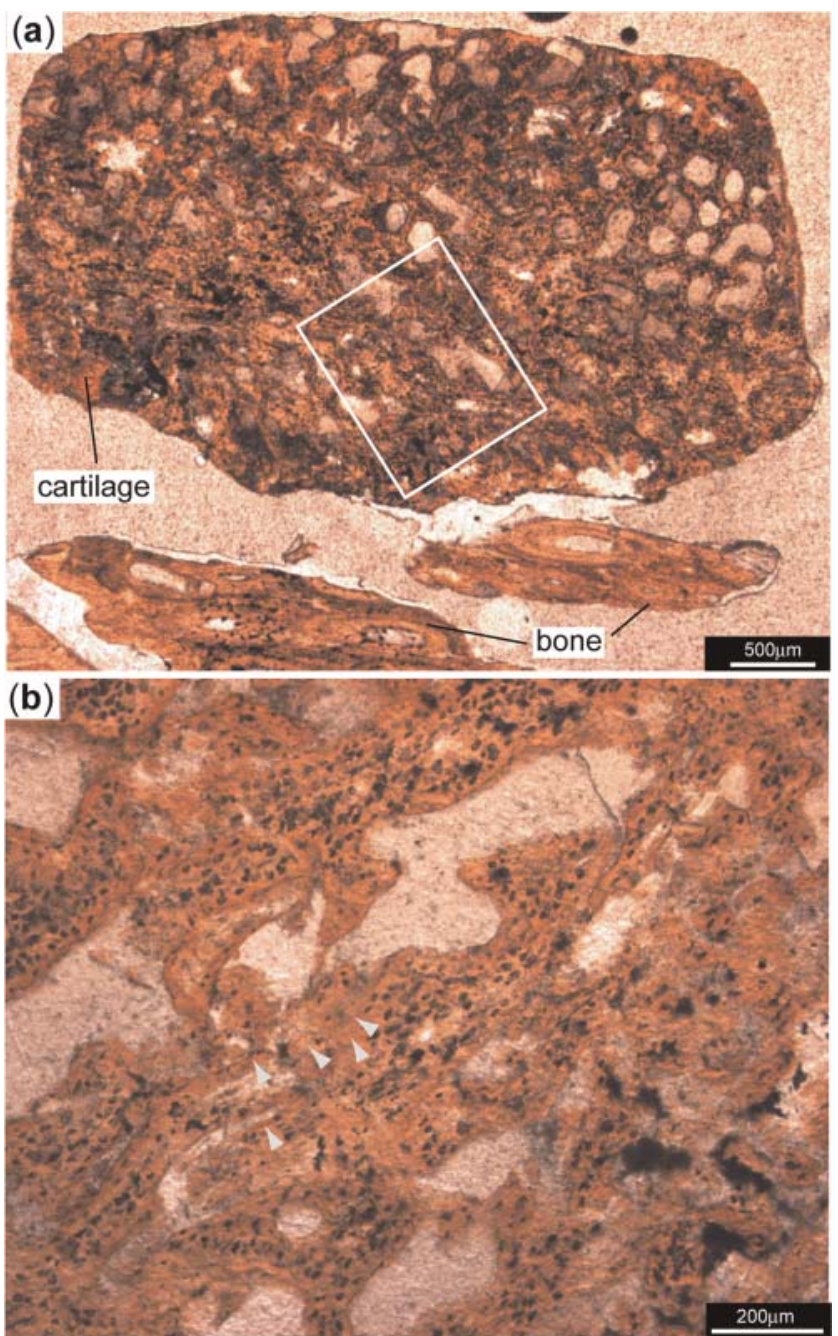

Fig. 4. Thin-section photographs: (a) cartilage and bone; (b) detail of cartilage as indicated in white rectangle in (a); white arrows indicate a zone of metaplastic bone with small parallel lines typically developed in this tissue.

\section{Discussion and conclusions}

\section{Microscopic and macroscopic features}

The macroscopic and histological differences between the cartilage and the underlying bone tissue allow us to unambiguously distinguish them from each other. Perforating pores in the calcified cartilage represent small cylindrical extensions of the marrow cavity (Reid 1997). The spaces within the cartilage layer probably were excavated by marrow chondroclasts, typically associated with endochondral ossification (Reid 1997). In contrast to the calcified cartilage layers of juvenile dinosaurs (e.g. Horner et al. 2000), a zone of hypertrophied and multiplied cartilage cells is not preserved here. Together with the absence of an absorption zone and other evidence such as body size,

Fig. 3. EDX photographs, showing the sampled areas of bone (a) and cartilage (c); the area within the white rectangle is magnified in (b) and (d), respectively. The arrows at the left side of the mineral labels mark the sampled spots. 
completely fused neurocentral sutures and strong muscle insertion scars, this indicates a later ontogenetic stage. Nevertheless, calcified cartilage defines the growth zone underneath the soft articular cartilage in the living animal, as confirmed by the similar apatite composition of bone and cartilage. The preserved part represents probably the underlying layer of calcified cartilage, whereas the overlying uncalcified cartilage of the articular cap has not been preserved (Geist \& Jones 1996; Reid 1997; Horner et al. 2000).

The microscopic structure of the cartilage of Cetiosauriscus greppini mainly resembles hyaline cartilage, and in patches fibrous cartilage of extant vertebrates (Kühnel 1985). The chondrocytes are not hypertrophied and the cartilage contains fibrous tissue locally. Thus, the cartilage may represent partially metaplastic tissue, generated by progressive mineralization from normal hyaline cartilage into fibrocartilage (Haines \& Mohuiddin 1968), and appearing in areas where articular or fibrous cartilage and tendons approach the bone surface. The fibres preserved within the cartilage are remnants of the calcified aponeuroses and tendons of forelimb muscles.

All tissue present in the thin section is uncompressed; presumably because of the spongier and therefore more compressible centre of the bone in comparison with the cartilage.

\section{Taphonomy}

Hitherto, mineralized cartilage in sauropods was known only from sternal or distal rib elements (Claessens 2004; Woodward 2005). None of the other limb bones of Cetiosauriscus greppini shows similar cartilage preservation and the taphonomical reasons for this are puzzling. The bones of $C$. greppini show few indications of transport, and fragile parts such as thin transverse processes of the vertebrae are preserved. The proximal and distal parts of the limb bones were abraded during diagenesis, but possibly also damaged during excavation. Obviously, the in vivo mineralization of the articular cartilage capsule enhanced its preservation potential. The missing cartilage on other bones may be explained by different diagenetic conditions that were only locally favourable for cartilage preservation (e.g. changes in pore water composition). Indications for this are slight colour differences between different bones of Cetiosauriscus greppini.

Alternatively, the articular cartilage capsule was mineralized only in this particular bone. The adaptation of this single bone to a certain loading regime, different from that of other limb bones, is unlikely. However, the cartilage preservation could be pathological mineralization caused by metabolic diseases, such as acroarthritis (Burr \& Martin 1989), caused either by an injury of the anconeal joint or by a metabolic disease of the individual. Pathologies to load-bearing bones (i.e. osteoarthritis of diarthrodial joints) are rarely reported for dinosaurs (Rothschild 1990; McWhinney et al. 2001) and the distal humeral articular surface bears no sign of a pathological disease, such as osteophytes or periostitis. Pathology of this bone could only relate to a metabolic disease causing increased mineralization of the cartilage, whereas the presence of cartilage and tendon remains at the distal humeral extremity itself would represent a natural condition in sauropods.

Cartilage on other limb bones could also have been mistakenly removed during original preparation. The greyish colour of the easily chipping off cartilage might have led to its removal, leaving only the superficially prepared humerus with cartilage. No documentation about the original preparation of this material remains.

\section{Palaeobiological implications}

In life, the articular cartilage of the distal humerus would most probably have been in contact with similar articular cartilage of

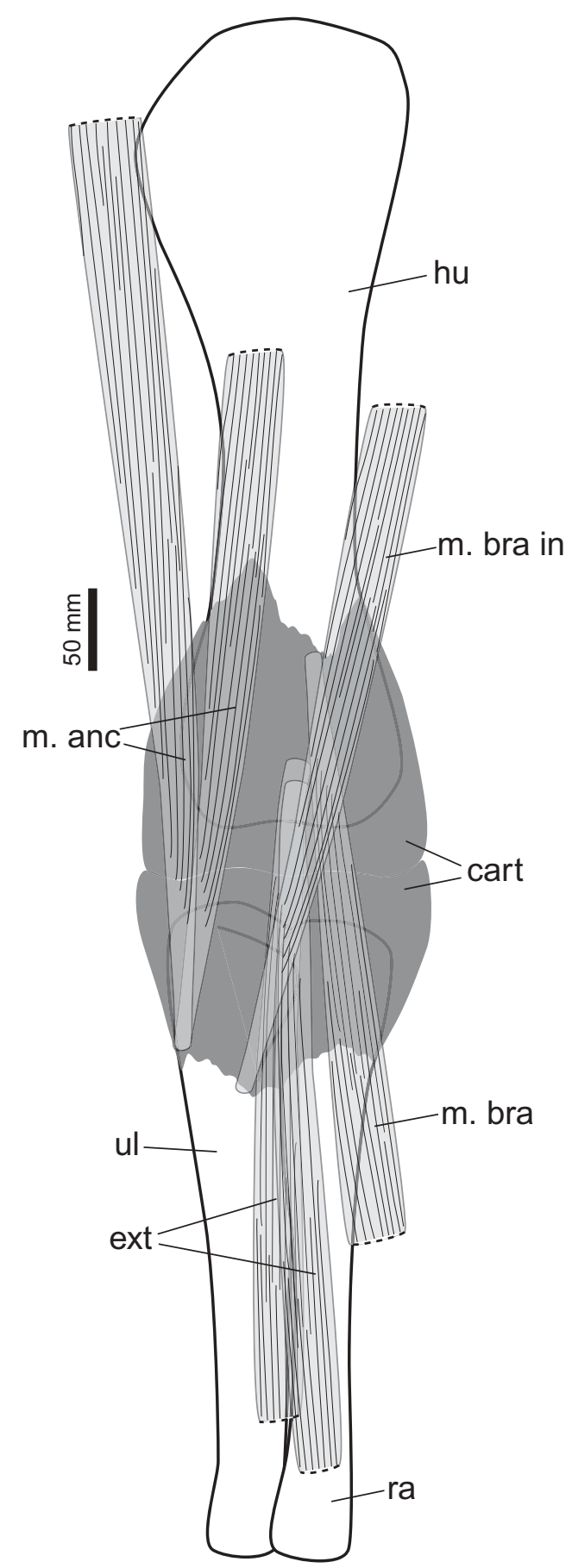

Fig. 5. Reconstruction of cartilaginous articular capsule around distal humerus, and proximal radius and ulna, caudal aspect, with possible important forelimb muscles around distal extremity of humerus (muscles are displayed only with their insertion around the distal humerus and adjacent parts). cart, cartilage; ext, forelimb extensor muscles; hu, humerus; $\mathrm{m}$. anc, m. anconaeus; $\mathrm{m}$. bra, m. brachialis; $\mathrm{m}$. bra in, $\mathrm{m}$. brachialis inferior; ra, radius; ul, ulna. 
the ulna and radius. The reconstructed articular cartilage capsule extends approximately from one-sixth to one-third of the distal side of the humerus, suggesting that sauropod dinosaurs possessed large articular limb capsules. As in extant archosaurs, where the morphology of the articular cartilage is dissimilar to bone surface morphology (Holliday et al. 2001; Horner et al. 2001; Bonnan 2003), the cartilage mass covered the distal articular surface of the humerus completely (Fig. 5).

The reconstructed articular cartilage capsule covers all insertion scars (e.g. medial and lateral ridge, olecranon fossa, ent- and ectepicondylus) present at the distal humerus. The furrows within the cartilage are interpreted as zones where tendons or aponeuroses crossed the cartilage to join the periosteum (Cooper \& Misol 1970; Tarsitano et al. 1989). This is consistent with the presence of calcified fibres of such tendons in the cartilage mass. At the bone surface, where cartilage is not preserved, similar connecting structures are exposed as small oval foramina. Reconstructions of sauropod limb musculature show that at least $\mathrm{m}$. coracoantebrachialis, branches of $\mathrm{m}$. anconaeous, $\mathrm{m}$. brancialis and $\mathrm{m}$. brachialis inferior, and major manus extensor and manus flexor series could have interacted with the distal articular cartilage capsule at the humerus (Fig. 5). A gradual transition from weakly to strongly mineralized fibrous cartilage is hypothesized to be helpful to evenly transmit forces around the articular surface during muscle contraction (Cooper \& Misol 1970). The combination of mineralized and unmineralized fibrous cartilage gives a better resistance against shear force, making the whole structure less susceptible to failure (Cooper \& Misol 1970). Thus, if the mineralization of the hyaline cartilage and tendon fibres is not pathological, it might be an adaptive mechanism present in sauropods in response to mechanical forces acting on this joint.

Even if the strong mineralization of the cartilage is pathological, its existence has important implications for sauropod limb length. It is highly likely that the ends of the limb bones of sauropods bore large cartilage caps, prohibiting the free rotation of the bones and leading to very restricted limb movements during locomotion (Bonnan 2003). The preservation of a large articular capsule in Cetiosauriscus greppini verifies that limb lengths of sauropods must have been larger than apparent from the bones alone (Holliday et al. 2001; Bonnan 2003). Although the distal cartilage capsule is not completely preserved, we can estimate an overall thickness of at least $3-5 \mathrm{~cm}$ of cartilage between humerus and antebrachium. This implies that the length of the humerus of $C$. greppini was, by comparison with extant archosaurs (Holliday et al. 2001), 6-10\% larger than previously thought. It is plausible that the height to shoulder, and possibly hip, of all sauropod dinosaurs has been hitherto underestimated, making these largest of land animals even larger.

We thank A. Heitz (Natural History Museum Basel) for preparation, W. Tschudin (University of Basel) for core-drilling and thin sectioning, and S. Padzera (Zürich) for drawing. For technical support, we are indebted to E. Lehmann (Villigen) (neutron tomography), H. Schulz (Tübingen) (SEMEDX), and H.-U. Pfretzschner (Tübingen) (thin-section photographs). This paper has been improved substantially by reviews by P. Manning, D. Martill and D. Mcllroy. Current financial support is provided for D.S. by the Swiss National Science Foundation (SNF No. 200020-109131/1), and for O.W. by the German Research Foundation (DFG PF 219/21-2).

\section{References}

BonnAN, M.F. 2003. The evolution of manus shape in sauropod dinosaurs: implications for functional morphology, forelimb orientation, and phylogeny. Journal of Vertebrate Paleontology, 23, 595-613.

BurR, D.B. \& MARTIN, R.B. 1989. Errors in bone remodelling: towards a unified theory of metabolic bone disease. American Journal of Anatomy, 186, 186216.

Charig, A.J. 1980. A diplodocid sauropod from the Lower Cretaceous of England. In: JACOBS, L.L. (ed.) Aspects of Vertebrate History. Essays in Honor of Edwin Harris Colbert. Museum of Northern Arizona Press, Flagstaff, 231-244.

Charig, A.J. 1993. Case 2876: Cetiosauriscus von Huene, 1972 (Reptilia, Sauropodomorpha): proposed designation of C. stewarti Charig 1980, as the type specimen. Bulletin of Zoological Nomenclature, 50, 282-283.

Claessens, L.P.A.M. 2004. Dinosaur gastralia; origin, morphology, and function. Journal of Vertebrate Paleontology, 24, 89-106.

Cooper, R.R. \& Misol, S. 1970. Tendon and ligament insertion. Journal of Bone and Joint Surgery, 52, 1-21.

Francillon-Vieillot, H., de Buffrénil, V., Castanet, J., Géraudie, J. \& Meunier, F.J. 1990. Microstructure and mineralization of vertebrate skeletal tissues. In: Carter, J.G. (ed.) Skeletal Biomineralization: Patterns, Processes and Evolutionary Trends. Van Nostrand-Reinhold, New York, 471-530.

GEIST, N.R. \& JonES, T.D. 1996. Juvenile skeletal structure and the reproductive habits of dinosaurs. Science, 272, 712-714.

Glut, D.F. 1994. Dinosaurs. The Encyclopedia. McFarland, Jefferson, North Carolina.

Greppin, J.P. 1870. Description géologique du Jura bernois et de quelques districts adjacents. Matériaux pour la Carte géologique de la Suisse, 8, 1-357.

Haines, R.W. \& Mohuiddin, A. 1968. Metaplastic bone. Journal of Anatomy, 103, $527-538$.

Holliday, C.M., Ridgely, C., Sedlmayr, J.C. \& Witmer, L.M. 2001. The articular cartilage of extant archosaur limb bones: implications for dinosaur functional morphology and allometry. Journal of Vertebrate Paleontology, 21, $62 \mathrm{~A}$.

Horner, J.R., DE RicQlès, A.J. \& PAdiAn, K. 2000. Long bone histology of the hadrosaurid dinosaur Maiasaura peeblesorum: growth dynamics and physiology based on an ontogenetic series of skeletal elements. Journal of Vertebrate Paleontology, 20, 115-129.

Horner, J.R., PADIAN, K. \& DE RiCQLès, A.J. 2001. Comparative osteohistology of some embryonic and perinatal archosaurs: developmental and behavioral implications for dinosaurs. Paleobiology, 27, 39-58.

JANK, M., Meyer, C.A. \& Wetzel, A. 2006. Late Oxfordian to Late Kimmeridgian carbonate deposits of NW Switzerland (Swiss Jura): stratigraphical and palaeogeographical implications in the transition area between the Paris Basin and the Tethys. Sedimentary Geology, 186, 237-263.

KüHnEL, W. 1985. Taschenatlas der Zytologie und Mikroskopischen Anatomie. Georg Thieme, Stuttgart.

McWhinney, L., Carpenter, K. \& Rothschild, B.M. 2001. Dinosaurian humeral periostitis: a case of a juxtacortical lesion in the fossil record. In: TANKE, D.H. \& Carpenter, K. (eds) Mesozoic Vertebrate Life. Indiana University Press, Bloomington, 364-377.

Meyer, C.A. \& Thüring, B. 2003. Dinosaurs of Switzerland. Comptes Rendus Palevol, 2, 103-117.

ReID, R.E.H. 1997. How dinosaurs grew. In: Farlow, J.O. \& Brett-Surman, M.K. (eds) The Complete Dinosaur. Indiana University Press, Bloomington, $403-413$.

RothsChILD, B.M. 1990. Radiologic assessment of osteoarthritis in dinosaurs. Annals of Carnegie Museum, 49, 295-301.

Tarsitano, S.F., Rie $\beta$, J. \& Frey, E. 1989. On the method of tendon attachment to bone. Sonderforschungsbereich 230, Natürliche Konstruktionen, 2, 105-110.

von Huene, F. 1922. Ueber einen Sauropoden im oberen Malm des Berner Jura. Eclogae Geologicae Helvetiae, 17, 80-94.

von HuEnE, F. 1927. Sichtung der Grundlagen der jetzigen Kenntnis der Sauropoden. Eclogae Geologicae Helvetiae, 20, 444-470.

WINGS, O. 2004. Authigenic minerals in fossil bone from the Mesozoic of England: poor correlation with depositional environments. Palaeogeography, Palaeoclimatology, Palaeoecology, 204, 15-32.

WoODWARD, A.S. 1905. On parts of skeleton of Cetiosaurus leedsi, a sauropodus dinosaur from the Oxford Clay of Peterborough. Proceedings of the Zoological Society of London, 1, 232-243.

Woodward, H.N. 2005. Bone histology of the titanosaurid sauropod Alamosaurus sanjuanensis from the Javelina Formation, Texas. Journal of Vertebrate Paleontology, 25, 132A. 